\title{
Contributions to the knowledge of the fauna of Caddisflies (Insecta : Trichoptera) from south-east France, with description of new taxa
}

\author{
L. Botosaneanu ${ }^{1}$, J. Giudicelli2** \\ ${ }^{1}$ Zoölogisch Museum Universiteit van Amsterdam, Plantage Middenlaan 64, 1018 DH Amsterdam, The Netherlands. \\ 2 Maison Régionale de l'Eau, Boulevard Grisolle, 83670 Barjols, France. (E-mail : jb.giudicelli@wanadoo.fr)
}

\begin{abstract}
South-eastern France is highly interesting for hydroentomology, in particular for caddisflies. Its lower zones are communication corridors for the fauna of the Apennines on one hand, and for that of the Pyrenees and Cantabric Cordillera on the other hand. At the same time, its high mountain massifs are inhabited by a fauna including endemic elements vicarious with other Alpine massifs, and having sometimes a relict character. The present paper insists on the most interesting discoveries made by studying important collections from springs, streams and mountain rivers in various parts of the zone: taxa new for science (Plectrocnemia geniculata prealpina n. ssp., Hydropsyche subalpina n. sp, Drusus biguttatus teunisseni n. ssp., Alpopsyche $\mathrm{n}$. g.), taxa new for the French fauna (Tinodes antonioi, T. dives consiglioi, Hydropsyche pictetorum, H. tenuis, Ylodes canus), and additional information (morphology, distribution) for a number of species.
\end{abstract}

Keywords : Trichoptera, crenal, rhithral, oropotamal, alpine wetlands, south-east France.

\section{Introduction}

During recent years, much material of Trichoptera from south-east France has been seen by the two authors, originating either from various limnological research projects in the region (J.G.), or from studies of collections made by members of the Netherlands Entomological Society (L.B.). The region is particularly interesting from this point of view : in its higher mountainous parts (southern Alps: départements of Alpes de Haute Provence, Alpes Maritimes, Hautes Alpes) Trichoptera include the main representatives of the alpine fauna, whereas the lower zones include in their fauna typically mediterranean taxa, like species from the Iberian peninsula or from Italy. The aim of the present paper is to emphasize the most important discoveries, du-

\footnotetext{
* Corresponding author : E-mail : jb.giudicelli@wanadoo.fr
}

ring identification of hundreds of specimens : taxa new for science, species new for the fauna of France, addition to the knowledge of certain species. All specimens mentioned are kept either in the Zoologisch Museum Amsterdam (Z. M. A.), mostly pinned, or in the collection of J. Giudicelli (preserved in alcohol).

\section{Hydroptila giudicellorum Botosaneanu, 1980 (Fig. 1)}

In the original description of this species (Botosaneanu 1980) a mediocre illustration had been given from the female (Figs 3 e-f). We provide now a more detailed illustration of the female terminalia in ventral view, and of the vaginal sclerites. The illustrated specimen, from the type locality (springs at Etang du Comte, in the Crau) had been sampled in October 1978, thus earlier than the type specimens. The association is not $100 \%$ sure, but nevertheless probably correct. 

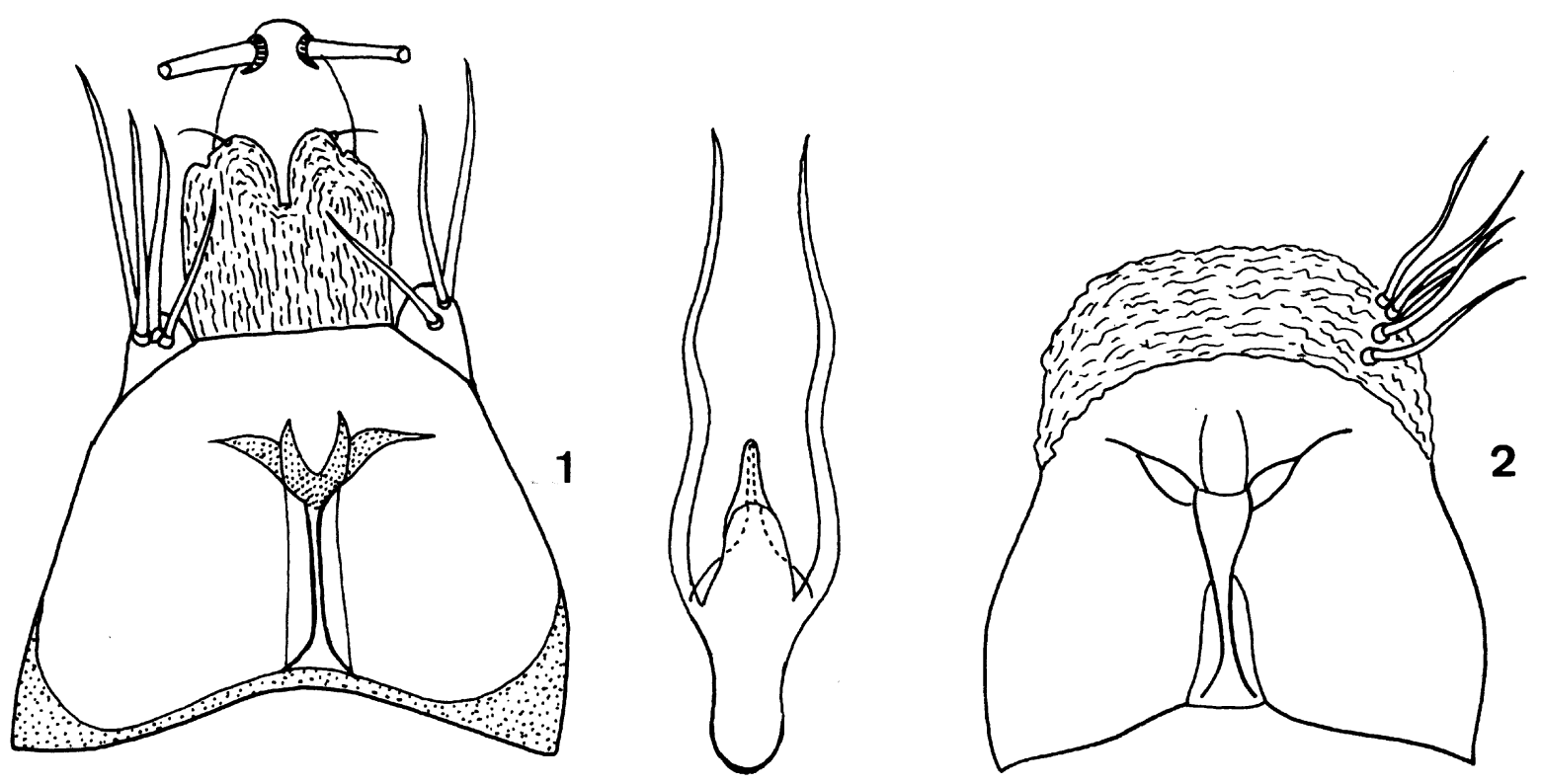

Fig. 1. Terminalia, female of Hydroptila giudicellorum Botosaneanu, ventral (right from this figure: the vaginal sclerites).

Fig. 2. Segment VIII of the female of Hydroptila phaon Malicky, ventral.

\section{Hydroptila phaon Malicky, 1976 (Fig. 2)}

This species, described from southern Greece (Epirus) and rediscovered in several zones of Italy (Cianficconi 2002: 352), has already been recorded from a locality in south-east France (Malicky 2002), but its female remained unknown. We illustrate here the VIIIth abdominal segment of the female in ventral view. We could examine 4 males and 1 female sampled by G.E. Langohr, between 11 and 22.VII.1982 at Les Mées, on the river Durance (département Alpes de Haute Provence), as well as 2 males caught by Y. Galvin (22.VII.1984) on the river Verdon at $620 \mathrm{~m}$ a.s.l. (same département).

\section{Plectrocnemia geniculata prealpina n. ssp.} (Figs 3-7)

\section{Material and localities}

Male holotype and one male paratype: département Hautes Alpes, Réotier (upper course of river Durance) at $1050 \mathrm{~m}$ a.s.1. (15.VIII.1992, leg. A.P.J.A. Teunissen); 1 male paratype : département Bouches-du-Rhône, massif of Sainte Baume, near spring at $800 \mathrm{~m}$ a.s.l. (VI.1980, leg. J. Giudicelli); 1 male paratype : département Var, upper course of the Siagne, on the spring «de la Foux», $230 \mathrm{~m}$ a.s.1. (26.VI.2001, leg. J. Giudicelli); 2 males ex nympha: département Alpes Maritimes, Parc National du Mercantour, spring near Ingolf bridge on the upper course of Tinée river, $2000 \mathrm{~m}$ a.s.l. (10.VII.2001, leg. J. Giudicelli); 1 male ex nympha: département Alpes Maritimes, Parc National du Mercantour, spring Les Clots, upper course of river Roya, 1885 m a.s.l. (25.VII.2002, leg. M. Derrien). Holotype, and two male paratypes in the Z.M.A. collections; remaining specimens in the collection of J. Giudicelli. One pinned male, not labelled as paratype, from Switzerland (Sils) is, too, in the Z.M.A. The female is unknown.

\section{Description}

Forewing length: $10-11.5 \mathrm{~mm}$; forewing colour light brown, membrane speckled with brown. Male genitalia (Figs 3-7). Dorsal lobe of segment X entirely membranous, with distinct but not deep median incision. Paraprocts (sclerotized part of segment X ; see Nielsen 1957: 46-47, Figs 23-24 - for Polycentropus) narrow and straight on most of their length, curved to the interior and ventrad in their distal quarter bearing 6-9 short spines on the external edge. Superior appendages: lateral lobes triangular in side view, with apex clearly rounded; medio-ventral lobes with two setose processes separated by deep incision; intermediate ap- 

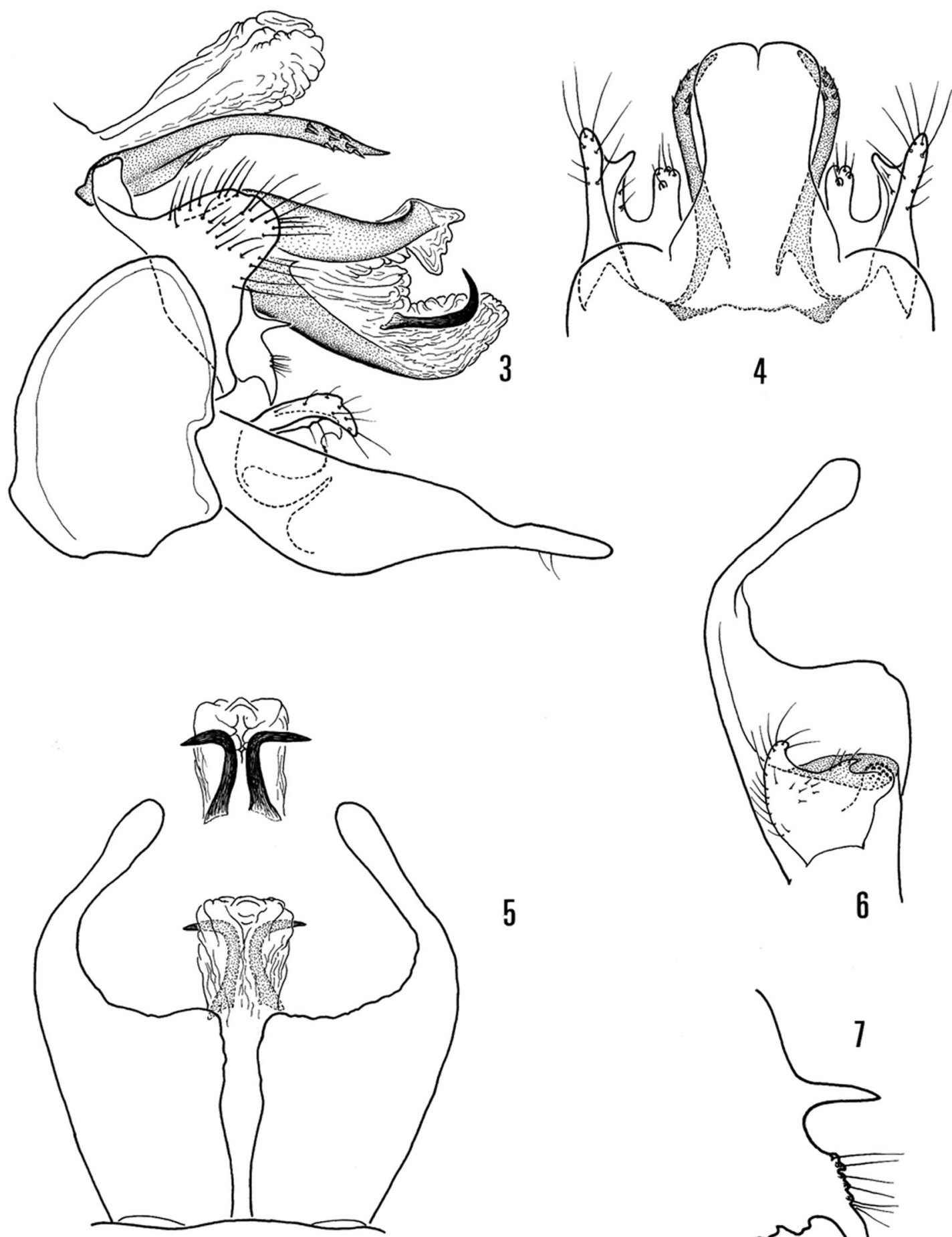

4
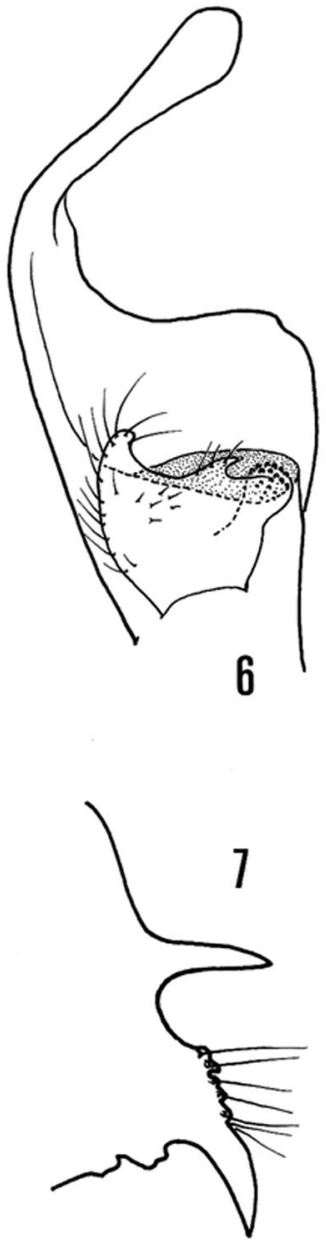

Figs 3-7. Male genitalia of Plectrocnemia geniculata prealpina n. ssp. 3: lateral; $4:$ dorsal; 5: inferior appendages ventral, and apex of aedeagus: 6: left inferior appendage, internal face ; 7 : intermediate appendage, lateral. 
pendages (sensu Mosely 1930) with two big teeth on their distal margin: one directed backwards, one strongly curved ventrad. Phallic complex: short aedeagus curved upwards; the lower process, longer than the upper one, bears in its apical membranous part two big hooks upwards curved in a right angle. Inferior appendages with very broad basal part and club-shaped distal part (these two parts are at a right angle on the internal side of the appendage).

\section{Discussion}

Plectrocnemia geniculata Mc Lachlan, 1871, a species rather widely distributed in Europe, clearly differs from other species of the genus by numerous characters, e.g., by the characteristic shape of the male inferior appendages. Several subspecies of $P$. geniculata, all meridional, have been already described: $P$. g. corsicana Mosely, 1930 (Corsica, Sardinia, Morocco; see also Moretti et al. 1990) ; P. g. calabrica Malicky, 1971 (Calabria, Basilicata); P. g. almoravida Malicky, 1986 (south-east Spain); P. g. factiosa Moretti, 1991 (Sicily). In this complex of geographic races, corsicana Mos. and prealpina $\mathrm{n}$. ssp. can be distinguished from the remaining ones by the very narrow, spiniform paraproctal processes (which are distinctly more foliaceous, for instance, in $P$. geniculata geniculata: Roy et al. (1980 : Figs 5A, 5B).

The following characters allow distinction of prealpina from corsicana:

- median incision of dorsal lobe of segment X deeper in corsicana (Figs 8-9);

- spines of the lower aedeagus process like hooks curved in a right angle and with pointed tip in prealpina (Figs 3, 5); shorter, only very slightly curved (almost straight) and with blunt apex in corsicana (Figs 8-9);

- distal margin of «intermediate appendages», in dorsal view, with 3 teeth separated by deep incisions in prealpina (Figs 3, 5), by wide and shallower ones in corsicana (Figs 8-9);

- «intermediate appendages» in lateral view clearly distinct in the two subspecies (Figs 7, 11, 12);

- inferior appendages of prealpina with broad proximal part and club-shaped distal part (Figs 5-6), both parts narrower in corsicana (Fig. 10).

It may be added that the undoubtedly interesting geographic variability of this species should make the object of a revision, the various published descriptions / illustration, as well as the terminology used, being quite non-standardized.

\section{Habitat}

Four species of Plectrocnemia are recorded from south-east France:

- P. praestans Mc Lachlan, 1884, known from Piemonte and from Liguria, is rather frequently found in the Mercantour massif (Alpes Maritimes); recorded by Malicky (2002) from a locality at $1500 \mathrm{~m}$ a.s.l., it has been caught by us from springs and from lake outlets between 1885 and $2410 \mathrm{~m}$ a.s.l. P. praestans seems to be a more stenothermic element than the two other species.

- P. conspersa Curtis, 1834 has been frequently caught from numerous streams (crenal, epirhithral) belonging to most hydrographic basins, between 100 and $1200 \mathrm{~m}$ a.s.1.

- P. geniculata prealpina $\mathrm{n}$. ssp. is more seldom than conspersa, being caught uniquely from the crenal (between 230 and $2000 \mathrm{~m}$ a.s.1.). The altitudinal distribution of both species in south-east France is similar to that observed elsewhere; for instance, in the Pyrenees $P$. geniculata replaces $P$. conspersa at higher altitudes (Décamps 1967).

- P. brevis Mc Lachlan, 1871 has been sampled only from one spring: source de Macruera, near the banks of River Caïros (a tributary of river Roya, département Alpes Maritimes, in the Parc National du Mercantour, $1260 \mathrm{~m}$ a.s.1.; 2 male metamorphotypes, 23.VII.2003, M. Derrien coll.).

\section{Tinodes antonioi Botosaneanu \& Taticchi- Vigano, 1974}

Known from various provinces of Italy (Cianficconi 2002) and also recorded from Slovenia (Krusnik \& Urbanic 2002), this species is new for the fauna of France; it has been sampled by one of the authors (J.G.) on the banks of a water course in the Alpes Maritimes: le Loup (1 male, 1 female: Pont du Loup, 1070 m a.s.l., 11.VII.1988; 1 male: Bar sur Loup, 120 m a.s.1., 11.VII.1988), as well as by G. Le Guellec on two streams at Barjols, département Var, 240 m a.s.l. (Ruisseau de Varage, 8.VI.2003, 1 male; Eau Salée, 9.VI.2003, 1 male).

\section{Tinodes dives consiglioi Botosaneanu, 1980}

This subspecies, originally described from specimens sampled from a spring of central Italy, is known from numerous localities in all parts of peninsular Italy: springs and streams between 200 and $1700 \mathrm{~m}$ a.s.l. 

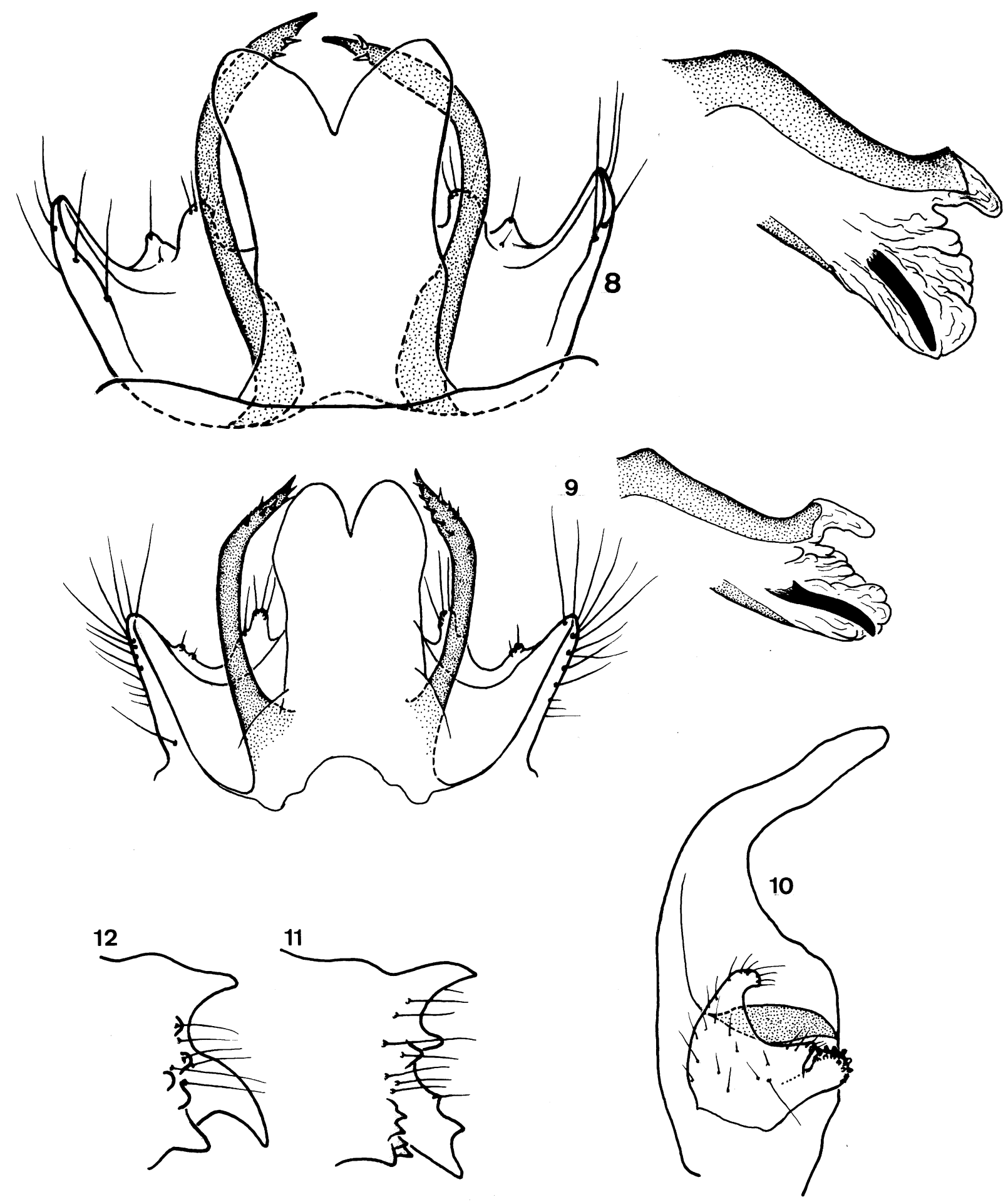

Figs 8-12. Male genitalia of Plectrocnemia geniculata corsicana Mosely. 8: dorsal view, and lateral view of aedeagus (specimen from Corsica: spring, Restonica valley); 9: idem (specimen from Morocco: spring in the Haut Atlas); 10: left inferior appendage, internal face (Corsica); 11: intermediate appendage, side view (Corsica); 12: idem (Morocco). 
(Moretti et al. 1997, Cianficconi 2002). A form seemingly intermediate between $T$. dives dives and $T$. dives consiglioi has been recorded from Spain (Asturias: Oviedo) by González \& Otero (1984) and later described as T. (d.) Cantabricus n. prosp. (Botosaneanu \& Gonzàlez 2001). This taxon is new for the fauna of France; it has been sampled at two localities:

- on the banks of the Siagne, a water course at the limit of the départements Var and Alpes Maritimes: 2 males sampled at its spring, a karstic exurgence at $630 \mathrm{~m}$ a.s.1. (26.VI.2001, leg. J. Giudicelli). Moreover, samples of «ripe» pupae (leg. J.G.) provide evidence of its presence along the whole upper course of the Siagne.

- in the spring of Sainte Anne at $790 \mathrm{~m}$ a.s.l., near the banks of river Maglia, a tributary of river Roya (département Alpes Maritimes; 3 males and 1 female, 24.VII.2003, M. Derrien leg.).

\section{Hydropsyche subalpina n. sp. (Figs 13-24)}

\section{Material and localities}

Holotype male, allotype female, 1 male paratype : département Var, spring of the Siagne, $630 \mathrm{~m}$ a.s.1., 26.VI.2001, J. Giudicelli; 1 male , 7 female paratypes: département Alpes de Haute Provence, pont (bridge) de Carejuan, on the banks of the Verdon, $640 \mathrm{~m}$ a.s.1., 27.VI.2001, J. Giudicelli. All specimens were caught by night with artificial light; they are preserved in alcohol. Abdomina of holotype, allotype and some paratypes were macerated in $\mathrm{KOH}$ and are kept in glycerin. Holotype, allotype, 1 male and one female paratypes are in the Z.M.A. collections; the remaining specimens are in the collection of J. Giudicelli.

\section{Description of adults}

Length of male forewing: $12.5-15 \mathrm{~mm}$; length of female forewing: $15.5-17 \mathrm{~mm}$; forewing colour light yellow or even whitish. Male genitalia (Figs 13-17, 19-20): median keel of segment $X$ long, narrow, with straight margins and apically pointed; in lateral view it is horizontal on most of its length but turns ventrad in its distal third. Dorsal depression of segment IX shallow and indistinctly limited distally; that of segment $\mathrm{X}$ is scarcely distinct; 6 long setae are inserted on the limit between the two depressions (Figs 13, 17). Segment $X$ : in dorsal view the central body of the segment is narrow, with deep, round apical sinus. Very short proximal «winglet» of the central body; distal «winglet» well individualized and protruding - in lateral as well as in dorsal view - (on it about 10 short, straight setae are inserted). Distally segment X shows - in lateral and in dorsal view - a pair of what could be described as rudiments of digitiform appendages, each rudiment having a ventral lobe with 4-6 setae, and sometimes also a small dorsal wart with one seta. Spinuligerous zones rather small, protruding, the spinules covering their distal and ventral parts. Ratio harpago / coxopodite : $1 / 2.28$ - $1 / 2.30$. In lateral view the harpago is flattened and upwards curved distally; in dorso-ventral view its margins are parallel, slightly curved, the apex being truncate. Phallus (Figs 13, 15-16, 19-20) in lateral view with gradually curved ventral side and with two bumps on the dorsal side; its diameter remains rather constant throughout its length; blunt apex, a slight dorsal anteapical depression; phallic «teeth» strongly developed, placed rather near the phallus' apex, distinctly shift ventrad but nevertheless well distinct also in dorsal view; the lateral lobes of the apical part of phallus are parallel.

Female genitalia (Fig. 18): dorsal lobe, more distally inserted than ventral lobe, narrow, arched, rounded; ventral lobe broad, triangular but blunt ending, with angular dorsal outline and slightly concave ventrally. Receptacle of harpago with elliptical sub-horizontal aperture. Duct broad but shallow, with rather indistinct walls.

\section{Description of larva (Figs 21-24)}

Ripe pupae («metamorphotypes») sampled from habitats having supplied adults of the new species, have enabled correct association and made possible the description of the $5^{\text {th }}$ instar larva. Seventh abdominal segment with gills. Ratio length / width of head: 1.06- 1.07. Frontoclypeus (Fig. 23) flat, widened in its middle - where its width is slightly less than that of the straight anterior margin, or equal to it; there are 3 light spots on the dark-brown background: one pair of larger, distinctly outlined spots in contact with and distad from the epistomial suture, and one less distinctly outlined spot in the posterior angle; in some specimens an indistinctly outlined light zone could be observed in contact with the anterior pair of spots. Pronotum with light-brown lateral parts, and darker median part forming a triangle (Fig. 21). Meso- and metanotum brown, slightly lighter on the sides. Posterior prosternites subrectangular, dark (Fig. 24).

\section{Discussion}

It is possible that the new species belongs to the «pellucidula-group», but it is rather distant from most species actually considered as belonging to it. The male genitalia resemble in some respects those of $\mathrm{H}$. aci- 

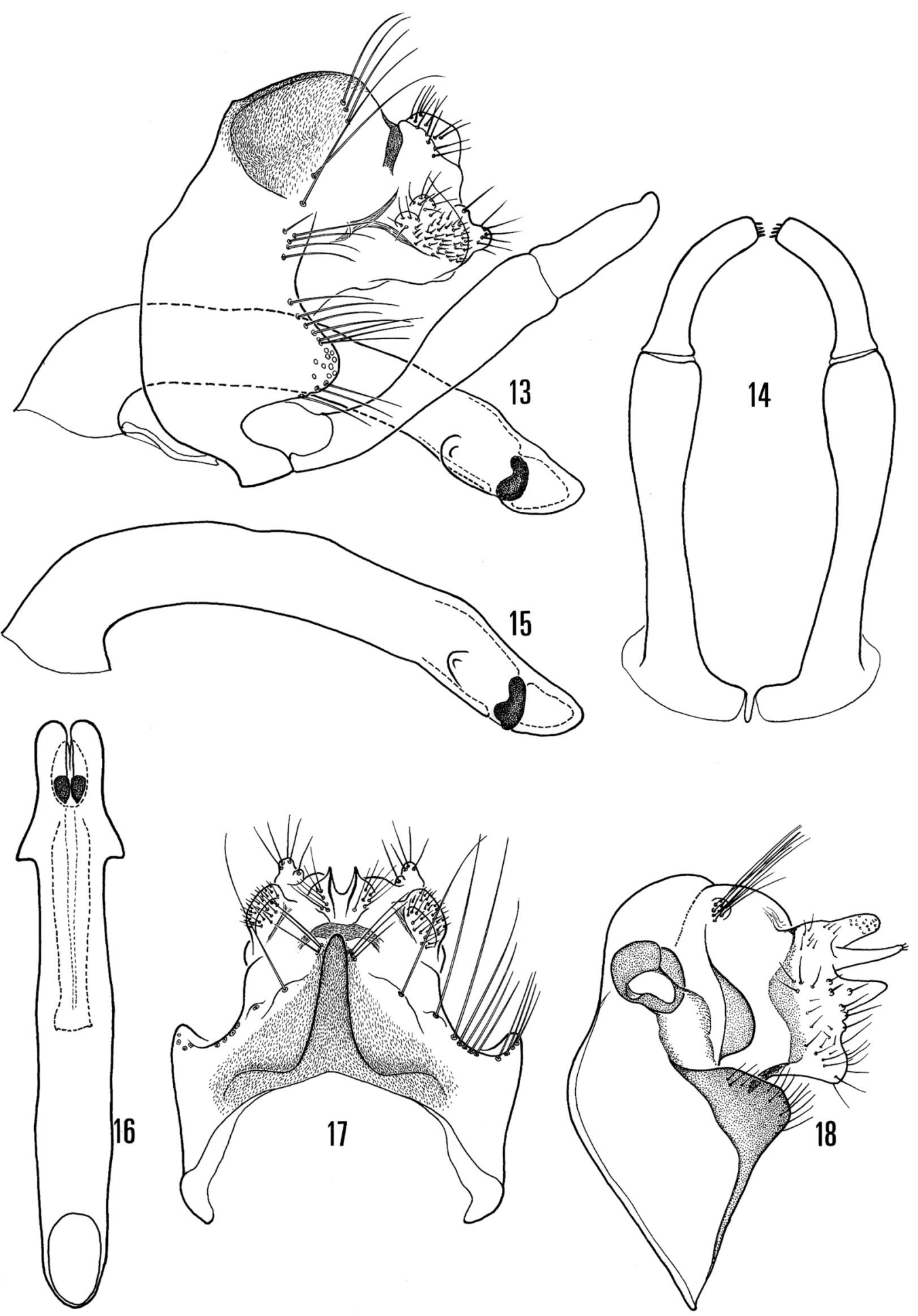

Figs 13-18. Genitalia of Hydropsyche subalpina n. sp. 13: lateral view; 14: inferior appendages, ventral; 15: phallus, lateral; 16: phallus, ventral; 17: dorsal view of male genitalia; 18: lateral view of female genitalia. 


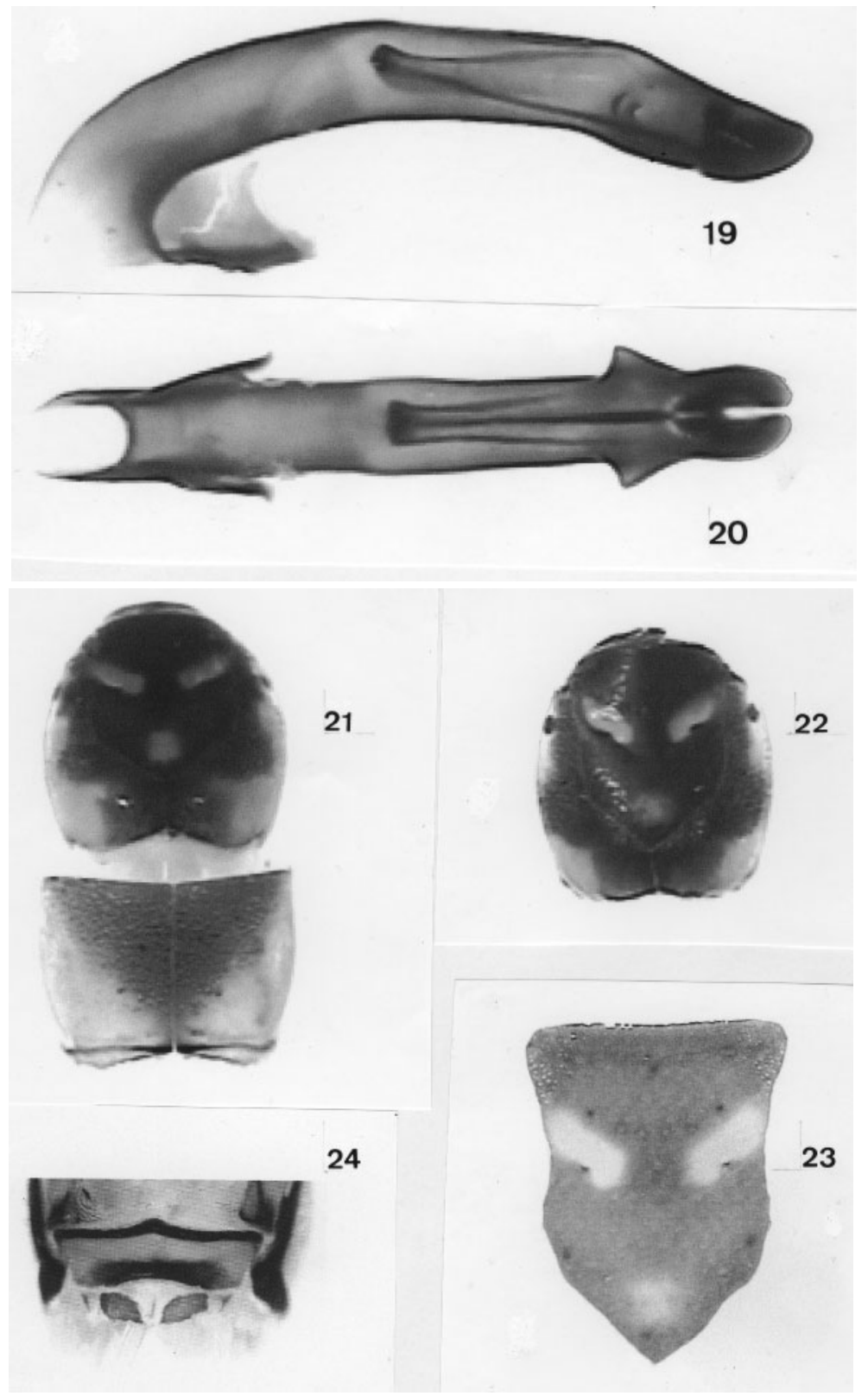

Figs 19-24. Male genitalia (phallus) and larva of Hydropsyche subalpina n. sp. 19: phallus, lateral; 20: phallus, ventral; 21: head and prothorax of larva, dorsal; 22: head of larva, dorsal; 23: frontoclypeus (from «ripe pupa»); 24: prosternite of the larva. (Photographs : Sophie Dandelot). 
noxas Malicky, 1981, a species described from northern Spain (province Gerona) on an actually uniquely known specimen (Malicky 1981: 340-341, tab. 1 O-S; the rather summary illustration of male genitalia in this publication has been re-used without notable improving in Malicky 1999). Segments IX and X seem to be identical in acinoxas and subalpina $\mathrm{n}$. sp.; in both species segment $\mathrm{X}$ bears «rudiments of digitiform appendages»; on the other hand, the keel of segment $\mathrm{X}$ is longer and narrower in subalpina which is also distinguished by its slightly upward curved tip of the harpago. But it is the morphology of the phallus which clearly allows distinction of the new species from acinoxas; the phallus of subalpina is much more robust than that of acinoxas; the two bumps on its dorsal side and the phallic «teeth» strongly developed and placed relatively near the apex are good distinctive characters (in the redescription of acinoxas - Malicky 1999 - we read «ist die Form ihres Phallus gut characterisiert: der Endteil ist lang, die Lateralzähne stehen ziemlich weit vom Ende entfernt»). There is, too, a significant difference in the forewing colour: light yellow in subalpi$n a$, dark in acinoxas («eine auffalend grosse und dunkle Art» : Malicky 1981). The larva of H. subalpina seems to be well characterized by the colour pattern of head and pronotum.

\section{Hydropsyche pictetorum Botosaneanu \& Schmid, 1973}

Described on specimens from Spain (Las Granjas) and recorded from rather many Spanish localities (Gonzalez et al. 1992) this species belonging to the instabilis-group is new for the fauna of France. We have seen 4 males from 3 sampling sites in the département Alpes de Haute Provence (Saint Donat, $480 \mathrm{~m}$ a.s.1., 25-26.VII.1979; l'Escale, 450m a.s.1., 13-17.VII.1982 - both sites near the banks of river Durance -; Montagne de Lure, 16.VII.1982; leg. G.E. Langohr) as well as 2 males from a locality in the département Alpes Maritimes (Bendejun, on the banks of river Paillon, at $260 \mathrm{~m}$ a.s.1., 10.V.1988; leg. J. Giudicelli). The genitalia of these specimens are exactly like those illustrated in the original description (Botosaneanu \& Schmid 1973: Fig. 2).

\section{Hydropsyche tenuis Navas, 1932}

Again, a species new for the fauna of France, and belonging to the same instabilis-group. The specimens seen by us are from Réotier (département Alpes de
Haute Provence, $1050 \mathrm{~m}$ a.s.l., 1 male caught by A.P.J.A. Teunissen with artificial light on the banks of the Durance), and from the Parc National du Mercantour (département Alpes Maritimes; 2 males, 2 females ex nympha, sampled by M. Derrien on 20.V.2002 and on 9.VII.2002 on the Caïros - a tributary of river Roya - , between 700 and $1000 \mathrm{~m}$ a.s.l.) . There is identity between these specimens and that illustrated by Botosaneanu \& Schmid (1973: Fig. 3) sub «Hydropsyche sp. ex gr. instabilis (n. sp. ?)»- which is indisputably H. tenuis. It should be noted, too, that numerous larvae sampled by one of the authors (J.G.) in the upper course of rivers of the Alpes Maritimes (le Loup, la Tinée, la Roya) could be identified as belonging to $H$. tenuis; they are well matching description and photographs published by Waringer \& Graf (1997: Figs 21, 30, 31) for this species.

Drusus biguttatus teunisseni n. sp. (Figs 2528)

\section{Material and localities}

Male holotype : département Hautes Alpes, Réotier, 1050 m a.s.1., 14.VII.1992, A. P. J. A. Teunissen. From $\mathrm{M}^{\mathrm{r}}$ Teunissen - coleopterologist to whom we have the pleasure to dedicate this new taxon - we learn that the specimen has been caught by night, with artificial light, on the banks of the Durance at «La Fontaine». It is pinned, abdomen in glycerin, in the Z. M. A. collections. Moreover : 4 males and 2 females, paratypes, from Lac d'Allos, 2200 m. a.s.l., Le Guellec (in alcohol, most specimens in the Z.M.A., one male in the collection of J. Giudicelli).

\section{Description}

Forewing length: $12.5 \mathrm{~mm}$. Antennae with thin, light annulations; head, thorax, abdomen: dark brown (pronotum slightly lighter, like the legs). Forewing brown (not very dark), a small, distinct white spot at the arculus, a white streak along the transverse vein receiving the anal veins. Hindwings with very strong brush of stiff setae (some brown, some yellow). Spurs: 1, 2, 2. Male genitalia: zone with tubercles of segment VIII pentagonal, tubercles coarse, black. Dorsal part of segment IX very narrow, ventral part normally developed, proximal limit convex. Superior appendages oval, slightly concave. The intermediate appendages are the most salient part of the genitalia; each appendage has at its root a small, pale, blunt lobe; the appendages, strongly sclerotized, black, are particularly thick-set, diverging only in their distal part; they are distinctly bilobed, distal lobe like a beak directed sidewards and 

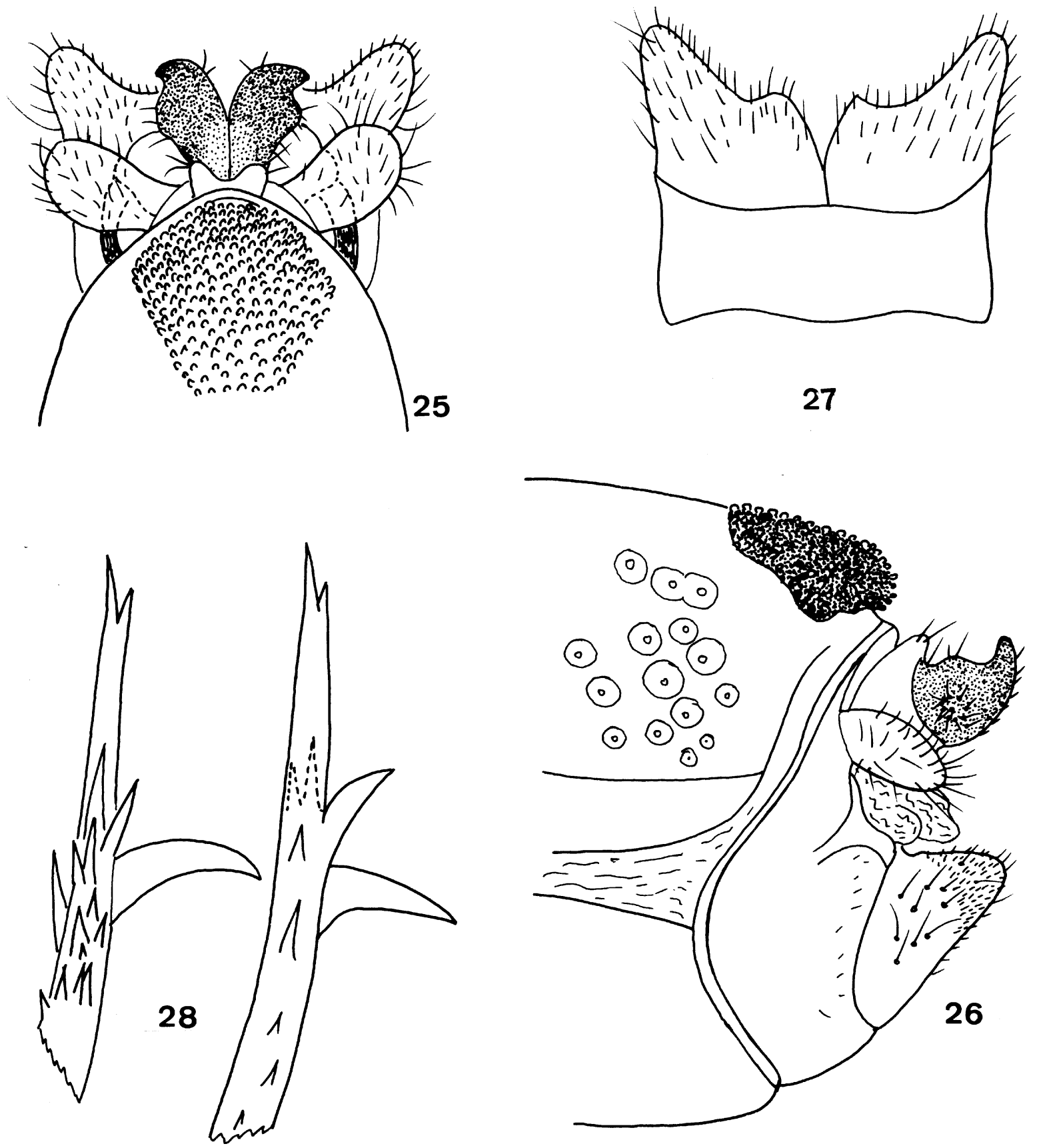

Figs 25-28. Male genitalia of Drusus biguttatus teunisseni n. ssp. 25: dorsal; 26: lateral; 27: gonopods, ventral; 28: distal part of the two parameres. 
upwards, proximal lobe rounded, distinctly protruding in lateral as well as in dorsal view; on the lateral face of each appendage a rosette of tiny spines. Inferior appendages small, in lateral view simple cones with obtuse apex, in ventral view distinctly bilobed, median lobes rather salient, lateral lobes short, with obtuse apex. Parameres armed, besides a variable number of short spines, with one or two strong anteapical hooks.

\section{Discussion}

Drusus biguttatus (Pictet, 1834) is known from numerous localities: Alps, northern Italy, «Mittelgebirge» of Central Europe, Carpathians, Balkan peninsula. French localities are listed (sub Potamorites) in Berland \& Mosely (1936); those from the French Alps obviously mark the western limit of the species' distribution. It could be interesting to know exactly how are looking specimens from populations of various French localities - for which descriptions and illustration are wanting. The new subspecies can be distinguished from $D$. biguttatus biguttatus by subtle but nevertheless relevant characters of the male genitalia: intermediate appendages more thick-set, distinctly bilobed (in dorsal and lateral view); inferior appendages in ventral view distinctly bilobed, median lobe well individualized, lateral lobe shorter and with more obtuse apex than in the nominative subspecies.

\section{Limnephilus sp. indet. (Figs 29-31)}

A female specimen of a big Limnephilus sampled by G.E. Langohr on 16.VII.1982 in the Alps de Haute Provence (Montagne de Lure; altitude unknown; sampling with the net near a mountain road accompanied by streams) could not be specifically identified; it is possible that this is a new species - which cannot be described in the absence of the male. Drawings of genitalia will allow recognizing the species when it will be again sampled.

Forewing length : $17 \mathrm{~mm}$. Yellow antennae; head, thorax, abdomen: amberlike (lateral parts of meso- and metanotum darker); legs, spurs, tibial spines: yellow; tarsal spines black. Forewings uniformly pale brownish; discoidal cell longer than its stalk. Hindwings strongly iridescent, discoidal cell shorter than its stalk. Our drawings have been examined by Mr Dave Ruiter, expert in Limnephilus, but an identification - specific, or at species-group level - did not prove possible.
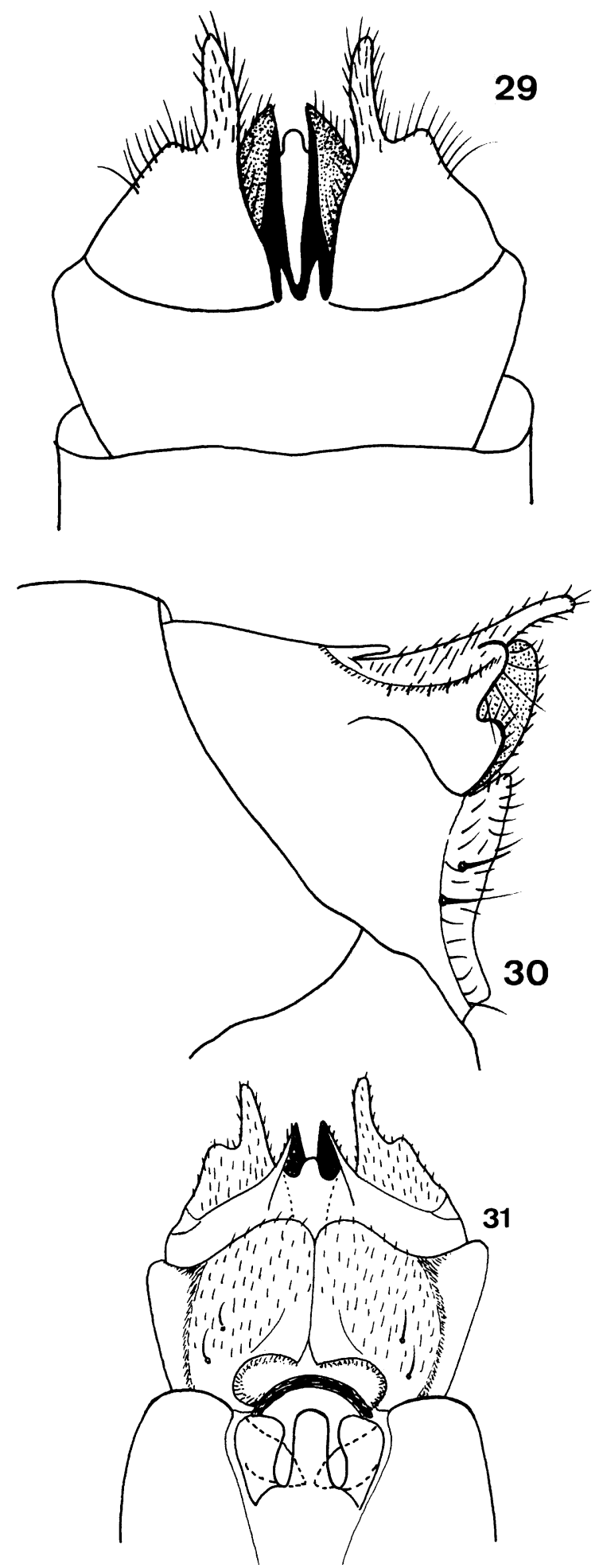

Figs 29-31. Female genitalia of Limnephilus sp. (n. sp. ?). 29: dorsal ; 30: lateral; 31: ventral. 


\section{Alpopsyche n. gen. for Rhadicoleptus uce- norum (Mc Lachlan, 1876)}

Study of specimens of $R$. ucenorum sampled either by Dutch entomologists (Z. M. A. collections) or as part of a project of inventory of the freshwater benthic fauna of the Parc National du Mercantour, has convinced us that this species is not correctly placed in genus Rhadicoleptus Wallengren, 1891, and that a new generic frame has to be created for it. Information on $R \mathrm{ha}$ dicoleptus ucenorum is mainly to be found in publications by Mc Lachlan (1876: 9-10, Pl. 30 Figs 1-8), Schmid (1955: 167), Malicky (1983: 185; 2001; 2002).

Diagnosis of the genus Alpopsyche nov. (Figs 3247)

Monotypic genus of Limnephilidae Stenophylacini. Rather small insects, not particularly slender; male size rather often surpassing that of the female (forewing length: male most often $11-13 \mathrm{~mm}$, seldom less than $10 \mathrm{~mm}$; female most often $10-12 \mathrm{~mm}$, seldom less than 10 or more than $12 \mathrm{~mm}$ ). Forewing (Fig. 32) with parabolic apex, membrane covered by very fine setulae contrasting with short rigid setae on most veins; discoidal cell more than two times longer than its stalk; almost vertical anastomosis; strongly marked pterostigma limited by the strongly curved terminal part of

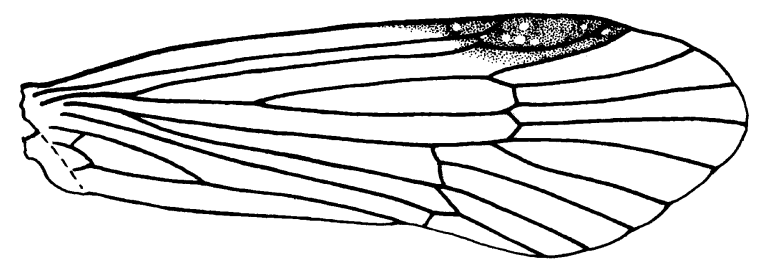

32

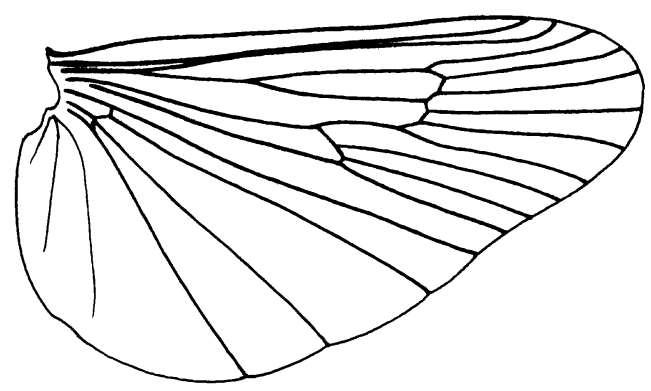

Fig. 32. Wings of Alpopsyche ucenorum (Mc Lachlan).
R1. Hindwing with very obtuse apex, discoidal cell 1.75-2.25 times longer than its stalk (male) or 1.5-2 times longer than it (female), anastomosis oblique against the body, Sc and R1 separated in their basal part but then with a rather long common section before again separating (no transverse vein connecting $\mathrm{Sc}$ and R1). Spurs : 1, 3, 4.

Male genitalia (Figs 33-39): segment VIII with black spinuligerous zone (spines fine) rather short but well developed laterally. Segment IX dorsally reduced to narrow frame, strongly developed laterally, and strongly shortened ventrally. The large superior appendages, with internal face slightly concave and slightly emarginated distally, are developed in a vertical plan; they meet on the median line where they are not distinctly limited, forming a sort of platform (to quote from Schmid's - 1950 - diagnosis of Hydatophylax: «leur bord interne se perd dans la cavité apicale»). The very small intermediate appendages are triangular, pointing upwards and forward; they are largely separated, and the base of each appendage is strengthened by a transversely placed, curved sclerite (the two sclerites forming an arch segment interrupted in its middle); intermediate appendages with their basal sclerites apparently lean on the platform formed by the median part of the superior appendages. There is no subanal plate. Inferior appendages long and narrow in their «free» part which is obliquely placed and ends in a point; their basal part, well elongated in a vertical plan, is laid against the IX ${ }^{\text {th }}$ segment, largely stretching out on it; ventrally, the inferior appendages form a semicircle, are basally coalescent on the median line, and distinctly separated from the margin of segment IX (their distal part being slightly sinuous and with obtuse apex). The phallus, with narrow phallobase, is characterized by a pair of slightly sclerotized anteapical formations turned downwards. The parameres, shorter than the phallus, are robust, slightly sinuous, and on the margin of their distal third long rigid spines are inserted. Female genitalia (Figs 40-47): vulvar scale with slender and rather long median lobe flanked by rather vast zones of sternum VIII from which it is separated only by a semimembranous cannelure. Segment IX with remarkable structure; tergum poorly developed, separated from segment $X$ by a sinuous limit. On the contrary, sternum IX is complex and strongly developed ; its proximal part is a massive piece, feebly chitinous, supple, wrinkled and folded (Figs 40, 42, 44-46 are made from different specimens); below this piece it has been possible to observe in some specimens (Fig. 45) a pair of membranous sacks which are certainly devaginable / invaginable depending upon the physio- 


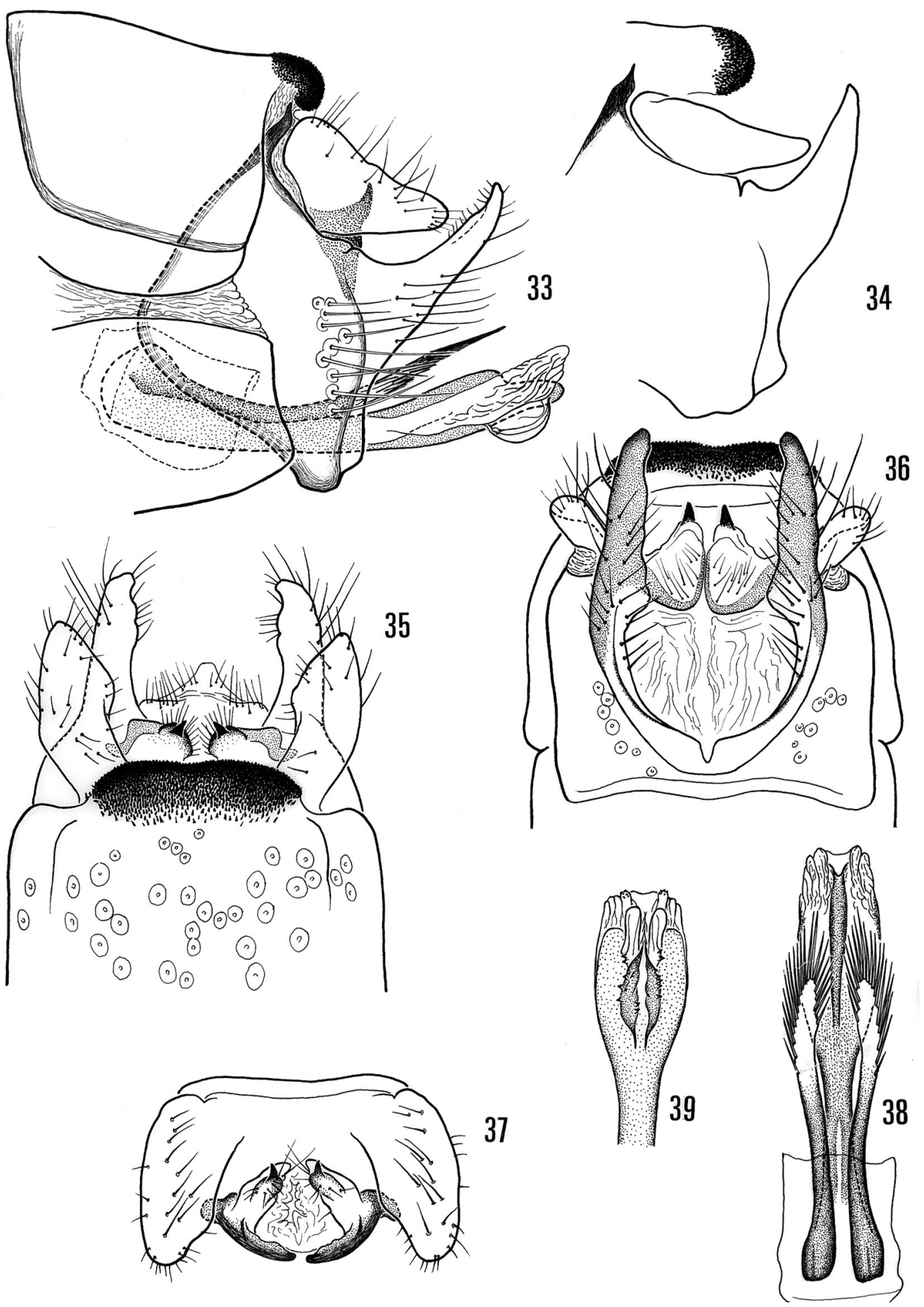

Figs 33-39. Male genitalia of Alpopsyche ucenorum (Mc Lachlan). 33: lateral; 34: idem (specimen with superior appendages obliquely placed); 35: dorsal; 36: ventral; 37: superior and intermediate appendages, apical view; 38: phallus, dorsal; 39: apex of phallus, ventral. 

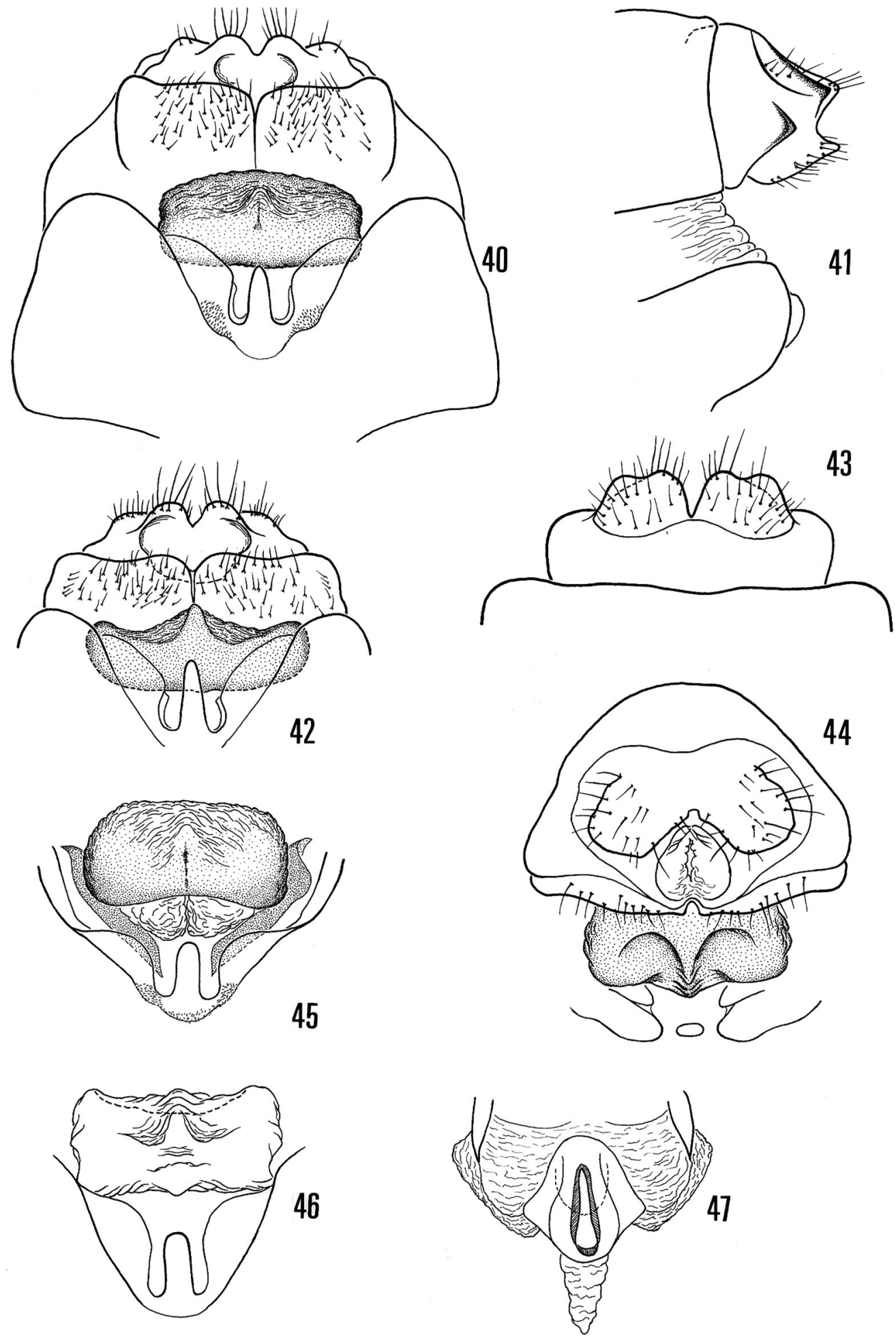

Figs 40-47. Female genitalia of Alpopsyche ucenorum (Mc Lachlan). 40 and 42: end of abdomen, ventral; 41: idem, lateral; 43: idem, dorsal; 44: idem, apical view; 45 and 46 vulvar scale and sternum IX; 47 : vaginal sclerite. 
logical condition, and which occupy the place of a «supragenital plate» - here lacking; distal part of sternum IX is a plate well developed especially transversally, covered by short setae and completely divided by a median line. Segment X (in dorso-ventral view) divided by a deep incision in two thickset lobes in their turn slightly bilobed; in lateral view the short «tubular piece» is slightly longer in its upper than in its lower part, the two parts separated by a rather deep sinus. Vaginal sclerite: Fig. 47.

\section{Generotype : Rhadicoleptus ucenorum (Mc La- chlan, 1876)}

\section{Localities and material used for the present study}

Numerous specimens have been sampled at three sites inside the Parc National du Mercantour: :

- st. 1: wet zone (2410 m a.s.l.) near the Torrent de Restefond (near Col de la Moutière, upper basin of the Verdon, département Hautes Alpes). 9 males and 6 females, 23.VII.2002, M. Derrien. Other Trichoptera caught : Metanoea flavipennis Pictet, Drusus discolor Rambur.

- st. 2: wet zone (2450 m a.s.l.) near the Torrent de Chaufrède (upper basin of the Tinée, département Alpes Maritimes). 21 males and 6 females, 27.VII.2002, M. Derrien. Other Trichoptera caught: Philopotamus ludificatus Mc Lachlan, Plectrocnemia praestans Mc Lachlan, Drusus discolor Rambur.

- st. 3: frontal spring of the Tinée (2300 m a.s.l., département Alpes Maritimes). 1 male, 24.VII.2002, M. Derrien. Other Trichoptera caught: Rhyacophila intermedia Mc Lachlan, Cryptothrix nebulicola Mc Lachlan, Drusus discolor Rambur.

These 3 sites are on a territory $3 \mathrm{~km}$ in diameter.

Other localities :

- st. 4 : Risoul (2050 m a.s.1.), upper course of the Durance (département Hautes Alpes). 1 male, VII. 1992, H. Berger. Other Trichoptera caught: Limnephilus sparsus Curtis, Stenophylax vibex Curtis.

- st. 5: Col d'Allos (2100 m a. s. 1.), upper bassin of the Verdon (département Alpes de Haute Provence). 1 female, 17.VII.1989, G.E. Langohr. The habitat is a «high mountain marshy pasture land drained by a streamlet» (G.E.L.).

- st. 6: Col d'Allos (2400 m a.s.1.), upper basin of the Verdon (département Alpes de Haute Provence). 3 males, 2 females, 21.VII.1982, 7.VIII.1985, 19.VII.1989, G.E. Langohr. Same type of habitat.
Most specimens are in the Z. M. A.; some are in the collection J. Giudicelli. A pair has been deposited in the Royal Ontario Museum, Toronto. Specimens from st. 1, 2 and 3 are in alcohol; those from st. 4, 5 and 6 are pinned.

\section{Habitat}

The habitat of A. ucenorum may be briefly described as follows: alpine species from helocrenic springs, marshy pasture land fed by water from upper course of streams, mostly above $2000 \mathrm{~m}$ a.s.l. Such type of habitat, restricted to some of the highest alpine valleys and sheltering rare and remarkable animal and plant species (boreo-alpine elements, glacial relicts), has been recognized as being of prioritary interest in the European Directive Natura 2000.

\section{Observations on mating}

One pair having been sampled in copula (st. 2), the following observation could be made without separating the insects. The phallus penetrates below the middle of the large proximal piece of sternum IX; the female «pinches» the male with the lobes of segment $\mathrm{X}$, below the superior appendages.

\section{Affinities}

A genus of Stenophylacini apparently showing some affinity with Alpopsyche is Hydatophylax Wallengren, 1891. Schmid (1950) has published a magistral monographic revision of this well characterized genus; this considerably facilitates comparison.

Genitalic characters apparently demonstrating such affinity are: for the male, position, structure, and reciprocal relations of superior and intermediate appendages, as well as the shape of inferior appendages and their relations with segment IX; for the female, most structural details of segments IX and X, and especially the proximal part of sternum IX with its particular structure (for Hydatophylax this is described by F. Schmid as being «molle, sans forme précise, souvent plissée»). However, there are differences of considerable importance between the two genera. In the male of Hydatophylax, segment IX is dorsally interrupted and replaced by a large horizontal cavity placed under tergite VIII; and the structure of the phallic apparatus is radically different in the two genera. In the female we find a difference in the vulvar scale, represented in Hydatophylax by an unique large lobe, mostly quadrangular. Of course, other options are possible. For example, by examining specimens and drawings sent by us, Prof. G.B. Wiggins could find some similarity (pterostigma, genitalia) with the monotypic genus Lep- 
totaulius Schmid, 1955, as well as with representatives of Chilostigmini (f.i. Chilostigmodes Martynov, 1914).

The main differences between Alpopsyche n. gen. and the similarly monospecific - but widely distributed and geographically variable - Rhadicoleptus will be summarized below (character states of Rhadicoleptus in brackets). F. wings rather uniformly coloured (conspicuous pattern of pale spots). H. wings: Sc and $\mathrm{Rl}$ with rather long common section (independently running throughout). Male genitalia: spinuligerous zone segm. VIII without lobes (trilobed); app. sup. large, medially meeting (relatively small, not meeting medially); intermed. app. very small, sharply pointed (stronger, apically obtuse); app. inf. long and narrow in oblique free part, basally coalescent on median line (strongly bulging posteriad, with sharp «spine» of dorso-apical angle, basally not coalescent on median line); phallus with anteapical bulge directed ventrad (directed dorsad). Female genitalia: tergum IX short, transversally developed (elongated, narrow); sternum IX proximal part large, transversally developed, supple, wrinkled and folded piece, supragenital plate topographically replaced by pair of evertible membranous sacks (large sclerotized supragenital plate narrowing distad, with median keel); sternum IX distal part, one large transversal plate with median longitudinal suture (pair of elongate plates separated by keel); segm. IX quadrilobed (bilobed).

\section{Ylodes canus (Navas, 1933) (Figs 48-53)}

From this species only the male holotype from Sobradiel (Zaragoza), sampled in 1932, has been known. Fortunately enough this specimen has been found, and Schmid (1949: Fig. 134) has published a good lateral drawing for its genitalia, allowing the recognition of the species. Dr. M. A. Gonzalez, who has examined our drawings, informs us that since the original description no additional specimen has been recorded from Spain. A pleasant discovery in the Z. M. A. collections has been that of 5 males and one female of Ylodes indisputably belonging to this species; the specimens have been sampled by G.E. Langohr at Les Mées (400 m a.s.l., département Alpes de Haute Provence); Mr. Langohr informed us that they were taken with artificial light, at 50-100 $\mathrm{m}$ from a canal dug during the sixties of the previous century and draining an important part of the water of river Durance for a chain of hydroelectric plants.

We give here a detailed illustration of the male genitalia, and also of those of the female - which remained undescribed (despite the fact that an «allotype» is men-
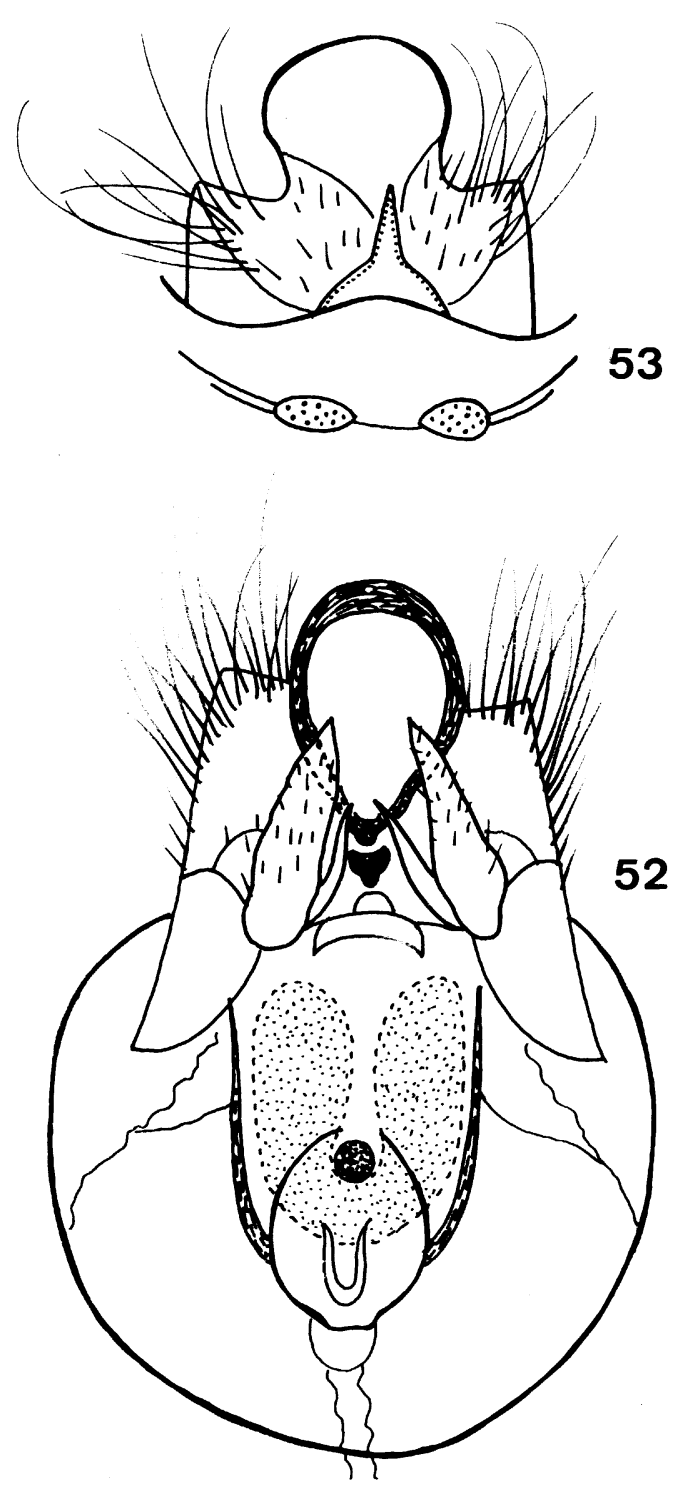

Figs 52-53. Female genitalia of Ylodes canus (Navas). 52: ventral; 53: fragmentary dorsal view.

tioned in Schmid 1949). The discovery in the Midi of France of what seems to be a large population of a species reputed endemic for Spain, is remarkable. 

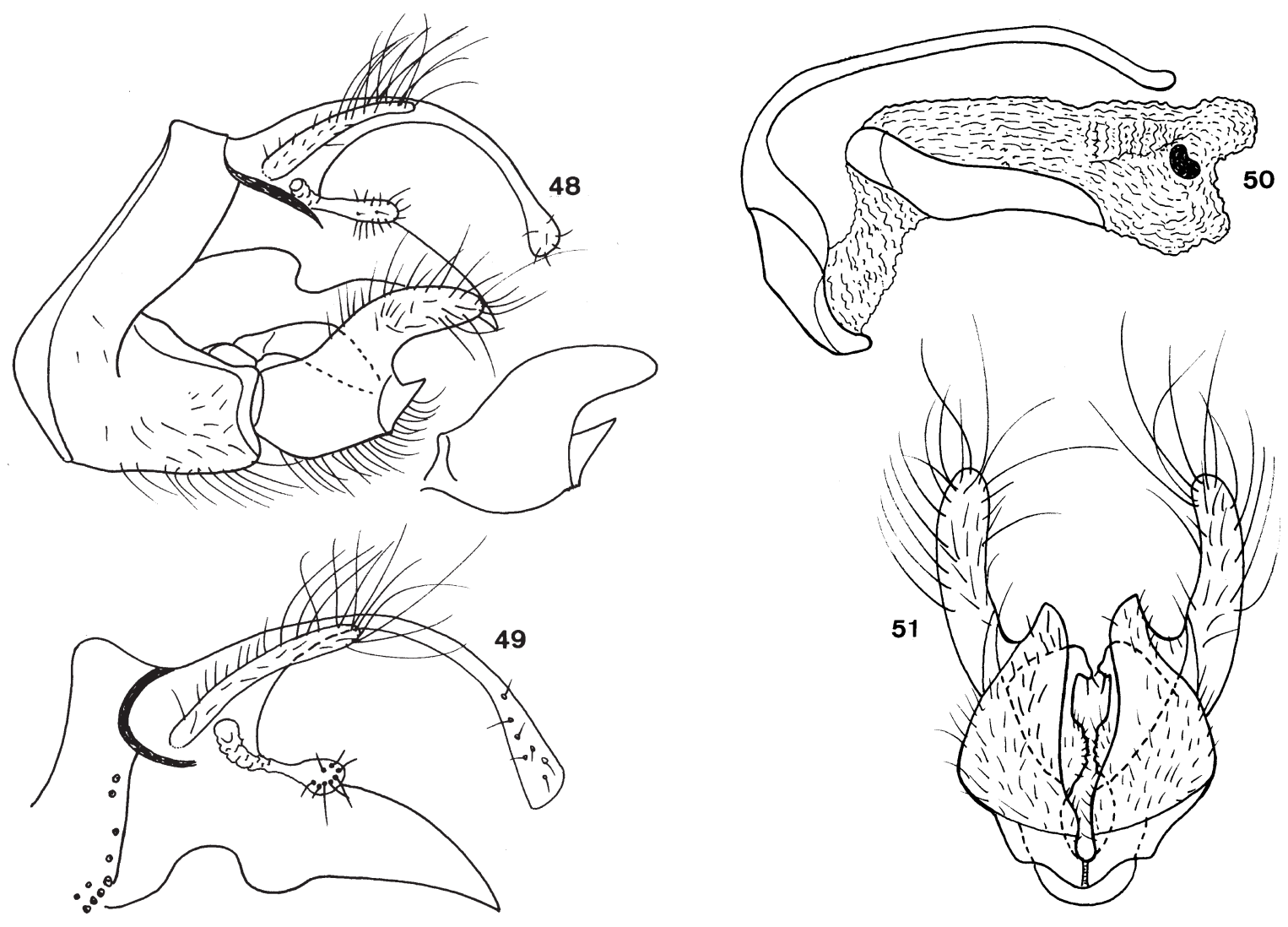

Figs 48-51. Male genitalia of Ylodes canus (Navas). 48: lateral, without the phallic apparatus (right from this figure: inferior appendage of another specimen, slightly different position); 49: segment $X$ and its appendages, another specimen, lateral; 50: phallic apparatus, lateral; 51: inferior appendages, ventral.

\section{Acknowledgements}

We express our gratitude to the following persons for having made available specimens used for the present study : H. Berger ( + ), M. Derrien and B. Lequette (staff of the Parc National du Mercantour), Y. Galvin, G. Le Guellec, G.E. Langohr, A.P.J.A. Teunissen. Our colleagues Dr. M.A. Gonzalez (Santiago de Compostella), D. Ruiter (Centennial, Colorado), Prof. G.B. Wiggins (Toronto \& Westport, Ontario) have kindly supplied information asked by us. Co-operation from Mr. W. Hogenes (curator of entomological collections of the Z. M. A.) has made possible study by the first author of pinned Trichoptera in these collections. Co-operation from Mr. G.D.M. Tweehuysen (Library of the Netherlands Entomological Society) has been, too, much appreciated.

\section{References}

Berland L. \& Mosely M.E. 1936. - Catalogue des Trichoptères de France. Ann. Soc. Ent. France, 105, 111-144.

Botosaneanu L. 1980. — Six nouvelles espèces ou sous-espèces de Trichoptères d'Europe méridionale. Bull. Zool. Mus. Amst., 7, 165-180.
Botosaneanu L. \& Gonzàles M.A. 2001. - Sur la variabilité de deux espèces ouest-paléarctiques de Tinodes Curtis (Trichoptera : Psychomiidae). Beaufortia, 51, 221-225.

Botosaneanu L. \& Schmid F. 1973. — Les Trichoptères du Muséum d'Histoire Naturelle de Genève. Rev. Suisse Zool., 80, 221-256.

Botosaneanu L. \& Taticchi-Vigano M. 1974. — Description d'une nouvelle espèce du genre Tinodes (Trichoptera, Psychomyiidae). Boll. Mus. Zool. Univ. Torino, 2, 9-14.

Cianficconi F. 2002. - The third list of Italian Trichoptera (1990-2000). Proceedings of the $10^{\text {th }}$ International Symposium on Trichoptera (W. Mey, ed.). Nova Suppl. Ent., Keltern, 15, 349-358.

Décamps H. 1967. — Ecologie des Trichoptères de la vallée d'Aure (Hautes-Pyrénées). Ann. Limnol., 3, 399-577.

González M.A. \& Otero J.C. 1984. - Observaciónes sobre los Tricópteros de la Peninsula Iberica. V. Tricópteros de los Picos de Europa (Norte de España). Bol. Asoc. española Ent., 8, 47-52.

González M.A., Terra L.S.W., Garcia de Jalon D. \& Cobo F. 1992. - Lista faunistica y bibliografica de los Tricópteros (Trichoptera) de la Peninsula Iberica e Islas Baleares. Listas de la flo- 
ra y fauna de las aguas continentales de la Peninsula Iberica, $\mathrm{Pu}-$ blicacion $\mathrm{n}^{\circ} 11: 200 \mathrm{pp}$

Krusnik C. \& Urbanic G. 2002. - Preliminary list of Slovenian Trichoptera. Proceedings of the $10^{\text {th }}$ International Symposium on Trichoptera (W. Mey, ed.). Nova Suppl. Ent., Keltern, 15, 359-364.

Mc Lachlan R. 1876. - A Monographic Revision and Synopsis of the Trichoptera of the European Fauna, Supplement 1, 1-12, pls. 24-31.

Malicky H. 1971. - Trichopteren aus Italien. Ent. Ztschr., Frankfurt a. M., 81, 257-265.

Malicky H. 1981. — Weiteres Neues über Köcherfliegen aus dem Mittelmeergebiet. Entomofauna, 2 (27), 335-355.

Malicky H. 1983. - Atlas of European Trichoptera. Series Entomologica, vol. 24, 298 pp. (Dr. W. Junk Publishers).

Malicky H. 1986. - Zwei neue spanische Köcherfliegen. Ent. Ztschr., 96, 26-28.

Malicky H. 1999. - Bemerkungen über die Verwandtschaft von Hydropsyche pellucidula Curtis (Trichoptera, Hydropsychidae). Linzer biol. Beitr., 31/2, 803-821.

Malicky H. 2001. - Notes on the taxonomy of Rhadicoleptus, Ptilocolepus and Pseudoneureclipsis. Braueria, 28, 19-22.

Malicky H. 2002. - Einige Köcherfliegen (Trichoptera) aus Frankreich und Italien. Entomofauna, 23 (1), 1-12.
Moretti G.P. 1991. — Nouvelles espèces et sous-espèces de trichoptères italiens et exemples de variabilité des populations des Alpes Méridionales et des Apennins. Pages 385-402 in Proc. $6^{\text {th }}$ Internat. Symp. Trich. (Tomaszewski C. ed.). A. Mickiewicz University Press, Poznan.

Moretti G.P., Botosaneanu L., Cianficconi F. \& Papagno F. 1990. Resoconto di una campagna autunnale di ricerche tricotterologiche in Sardegna (Ottobre 1988). Riv. Idrobiol., 29, 651-667.

Mosely M.E. 1930. — Corsican Trichoptera. Eos, 6, 147-184

Nielsen A. 1957. - A comparative study of the genital segments and their appendages in male Trichoptera. Biol. Skr. Kong. Danske Vidensk. Selskab., 8, 1-159.

Roy D., Décamps H. \& Harper P.P. 1980. - Taxonomy of male and female Plectrocnemia (Trichoptera : Polycentropodidae) from the French Pyrenees. Aquat. Insects, 2, 19-31.

Schmid F. 1949. — Les Trichoptères de la collection Navas. Eos, 25, 305-426.

Schmid F. 1950. — Le genre Hydatophylax Wall. (Trichopt. Limnophilidae). Mitt. Schweiz. Ent. Ges., 23, 265-296.

Schmid F. 1955. - Contribution à l'étude des Limnophilidae (Trichoptera). Mitt. Schweiz. Ent. Ges., 28 (Beiheft), 1-245.

Waringer J. \& Graf W. 1997. — Atlas der österreichischen Köcherfliegenlarven. Facultas Universitätverlag, 1-286. 